\title{
SENAM KAKI EFEKTIF MENGOBATI NEUROPATI DIABETIK PADA PENDERITA DIABETES MELLITUS
}

\author{
Camalia Suhertini ${ }^{1}$, Subandi $^{2}$ \\ ${ }^{1,2}$ Program Studi Keperawatan Bogor, Politeknik Kesehatan Bandung \\ Email: camaliasudibyo@ymail.com
}

\begin{abstract}
Effectiveness of foot exercise to treat Diabetic Neuropathy in Patients with Diabetes Mellitus. Foot exercises can prevent injury and help blood circulation of the foot. This study was to know the effectiveness of foot exercises to treat of diabetic neuropathy in patients with diabetes mellitus. The research design was the "Quasi-experimental pre-post test with control group", with foot exercises as intervention. Minimum sample of intervention group were 33 people, and control group were 33 people. sample were take with purposive sampling. datas analyzed with Paired T-test. the results showed that foot exercises had a significant effect to reduce a sensation value of the patient feet with diabetic neuropathy in the intervention group $(\mathrm{p}=$ $0.000, \alpha=0.05$ ). Foot exercises in the intervention group had a significant effect to reduce the the physical assessment value of patient feet with diabetic neuropathy $(\mathrm{p}=0.000, \alpha=0.05)$. The result showed that there was differences in the average value of the sensitivity and physical assessment of the foot and toe, between the control group and the intervention group $(p=0.000, \alpha=0.05)$ after foot exercises. it can be concluded that foot exercises was effective to treat diabetic neuropathy in patients with diabetes mellitus.
\end{abstract}

Keywords: Foot exercises, Diabetic neuropathy

\begin{abstract}
Abstrak: Senam Kaki Efektif Mengobati Neuropati Diabetik pada Penderita Diabetes Mellitus. Senam kaki dapat mencegah terjadinya luka dan membantu melancarkan peredaran darah bagian kaki. Tujuan penelitian ini adalah mengetahui efektifitas senam kaki terhadap pengobatan neuropati diabetik pada penderita Diabetes mellitus. Desain yang digunakan dalam penelitian ini adalah "Quasi experimental pre-post test with control group" dengan intervensi Senam kaki. Sampel minimum sebanyak 33 orang kelompok intervensi dan 33 orang kelompok kontrol. Cara pengambilan sampel dengan purposive sampling. Cara pengolahan data dengan $T$ Paired test. Hasil penelitian didapatkan dari uji statistik bahwa senam kaki pada kelompok intervensi berpengaruh secara signifikan dalam menurunkan nilai sensasi kaki penderita neuropati diabetik ( $p=0.000, \alpha=0,05$ ). senam kaki pada kelompok intervensi berpengaruh secara signifikan dalam menurunkan nilai pengkajian fisik kaki penderita neuropati diabetik $(p=0.000, \alpha=0,05)$. Hasil penelitian didapatkan terdapat perbedaan rata-rata nilai sensitivitas kaki dan pengkajian fisik kaki, sesudah senam kaki antara kelompok kontrol dengan kelompok intervensi $(p=0.000$, $\alpha=0,05)$. Maka disimpulkan, senam kaki efektif terhadap pengobatan neuropati diabetik pada penderita Diabetes mellitus.
\end{abstract}

Kata kunci: Senam kaki, Neuropati diabetik

Diabetes Mellitus merupakan sekelompok kelainan heterogen yang ditandai oleh kenaikan kadar glukosa dalam darah atau hiperglikemia. Glukosa secara normal bersirkulasi dalam jumlah tertentu dalam darah. Glukosa dibentuk di hati dari makanan yang dikonsumsi. Insulin yaitu suatu hormon yang diproduksi oleh pankreas, mengendalikan kadar glukosa dalam darah dengan mengatur produksi dan penyimpanannya (Smeltzer and Bare, 2002). Diabetes mellitus terbagi atas Diabetes mellitus tipe I jika pankreas menghasilkan sedikit atau sama sekali tidak menghasilkan insulin sehingga penderita selamanya tergantung insulin dari luar, biasanya terjadi pada usia kurang dari 30 tahun. Diabetes mellitus tipe II adalah pankreas tetap menghasilkaan insulin kadang lebih tinggi dari normal tetapi tubuh membentuk kekebalan terhadap efeknya. Biasanya terjadi pada usia di atas 30 tahun karena kadar glukosa darah cenderung meningkat secara ringan tetapi progresif setelah usia 50 tahun terutama pada orang yang tidak aktif dan mengalami obesitas (Smeltzer and Bare, 2002). Penderita Diabetes mellitus bertambah jumlahnya dari tahun ke tahun.

Neuropati diabetik merupakan kerusàkan saraf yang disebabkan peningkatan glukosa darah, yang mengakibatkan sirkulasi darah ke sel menurun dan fungsi sel saraf akan menurun. 
Neuropati diabetik teridiri dari neuropati sensorik, motorik dan autonom. Neuropati sensorik sering mengenai bagian distal serabut saraf, khususnya saraf ekstremitas bawah. Gejala permulaannya adalah parestesia (rasa tertusuktusuk, kesemutan atau peningkatan kepekaan) dan rasa terbakar (khususnya pada malam hari). Dengan bertambah neuropati kaki terasa baal (matirasa). Penurunan terhadap sensibilitas nyeri dan suhu membuat penderita neuropati beresiko untuk mengalami cedera dan infeksi pada kaki tanpa diketahui (Smeltzer and Bare, 2002).

Neuropati diabetik atau kerusakan saraf merupakan komplikasi serius dari diabetes. Neuropati diabetik terkait dengan masalah suplai darah ke kaki dapat menyebabkan ulkus kaki dan penyembuhan luka lambat. Infeksi ini dapat mengakibatkan luka amputasi, 40-70\% dari seluruh amputasi ekstremitas bawah disebabkan oleh Diabetes mellitus (Sudoyo, 2006).

Penatalaksanaan Diabetes Mellitus terdiri dari pertama terapi farmakologi yaitu meliputi pemberian obat anti diabetes oral dan injeksi insulin. Kedua terapi non farmakologis yang meliputi perubahan gaya hidup dengan melakukan pengaturan pola makan yang dikenal sebagai terapi gizi medis, meningkatkan aktivitas jasmani, dan edukasi berbagai masalah yang berkaitan dengan penyakit diabetes mellitus yang dilakukan secara terus-menerus. Aktivitas jasmani atau olah raga untuk penatalaksanaan Diabetes mellitus yang dilakukan adalah olahraga yang terukur, teratur, terkendali dan berkesinambungan. Frekuensi yang dianjurkan adalah 3-5 kali perminggu. Intensitas yang dianjurkan sebesar 40-70\% (ringan sampai sedang). Salah satu jenis olah raga, yang dianjurkan adalah senam kaki (Barners, 2012).

Senam kaki adalah kegiatan atau latihan yang dilakukan oleh pasien Diabetes mellitus untuk mencegah terjadinya luka dan membantu melancarkan peredaran darah bagian kaki. Senam kaki ini bertujuan untuk memperbaiki sirkulasi darah sehingga nutrisi ke jaringan lebih lancar, memperkuat otot-otot kecil, otot betis, dan otot paha, serta mengatasi keterbatasan gerak sendi yang sering dialami oleh penderita Diabetes mellitus. Senam kaki ini dapat diberikan kepada seluruh penderita Diabetes mellitus dengan tipe 1 maupun 2. Namun sebaiknya diberikan sejak pasien didiagnosa menderita Diabetes mellitus sebagai tindakan pencegahan dini. Senam kaki ini berpengaruh untuk memperbaiki sirkulasi darah (Widianti,
2010). Senam kaki ini sangat dianjurkan untuk penderita diabetes yang mengalami gangguan sikulasi darah dan neuropati di kaki, tetapi disesuaikan dengan kondisi dan kemampuan tubuh penederita. Latihan senam kaki DM ini dapat dilakukan dengan cara menggerakan kaki dan sendi-sendi kaki misalnya berdiri dengan kedua tumit diangkat, mengangkat dan menurunkan kaki. Gerakan dapat berupa gerakan menekuk, meluruskan, mengangkat, memutar keluar atau ke dalam dan mencengkram jari-jari kaki (Soegondo, 2011).

Beberapa penelitian yang sejenis sudah dilakukan antara lain penelitian yang dilakukan Karnisius dan Artika tahun 2011 tentang pengaruh senam kaki terhadap sirkulasi darah pasien Diabetes mellitus di RSU Dr. Pringadi Medan, hasil penelitiannya adalah terdapat pengaruh senam kaki yang dilakukan 5 kali dalam seminggu terhadap sirkulasi darah dengan nilai $p=0,000$ (Hareva, 2011). Penelitian yang dilakukan oleh Julian, tahun 2010 tentang pengaruh senam kaki terhadap peningkatan sirkulasi darah kaki pada pasien DM di RSUP Haji Adam Malik Medan yaitu rata-rata sirkulasi darah kaki sebelum dilakukan senam kaki 0,94 mmHg dan sesudah dilakukan senam kaki terjadi peningkatan sirkulasi darah kaki menjadi 1,90 mmHg dengan nilai $p=0,000$ (Juliani, 2011). Priyanto S (2012) melakukan penelitian tentang pengaruh senam kaki terhadap sensitivitas kaki dan kadar gula darah pada agregat lansia Diabetes mellitus di Magelang, hasil penelitian senam kaki yang dilaksanakan 3 kali seminggu selama 4 minggu adalah kadar gula darah dan sensitivitas kaki lebih baik pada lansia setelah diberikan senam kaki.

Oleh karena itu, maka dilakukan penelitian ini dengan tujuan untuk mengetahui apakah senam kaki dapat berpengaruh terhadap nilai sensasi kaki dan pengobatan neuropati diabetik pada penderita neuropati diabetik.

\section{METODE PENELITIAN}

Penelitian ini menggunakan metoda kuasi eksperimental dengan pendekatan pre test-post test with control group design. Dengan tujuan untuk mengidentifikasi pengaruh senam kaki terhadap pengobatan neuropati diabetik pada penderita Diabetes mellitus antara kelompok intervensi dan kelompok kontrol. Desain penelitian ini dapat dilihat sebagai berikut ini: 


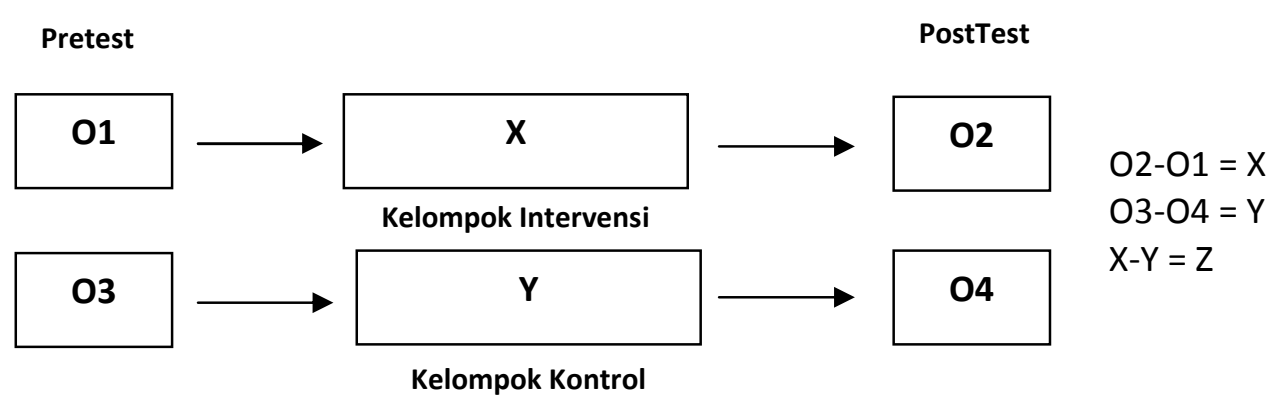

\section{Diagram 1. Desain Penelitian}

Keterangan:

O1 : Nilai sensasi dan pengkajian fisik kaki penderita Diabetes mellitus sebelum senam kaki pada kelompok intervensi

O2 : Nilai sensasi dan pengkajian fisik kaki penderita Diabetes mellitus setelah senam kaki pada kelompok intervensi

$\mathrm{X}$ : Deviasi/perubahan Nilai sensasi dan pengkajian fisik kaki penderita Diabetes mellitus sebelum dan sesudah senam kaki pada kelompok intervensi

O3 : Nilai sensasi dan pengkajian fisik kaki penderita Diabetes mellitus sebelum senam kaki pada kelompok kontrol

O4 : Nilai sensasi dan pengkajian fisik kaki penderita Diabetes mellitus setelah senam kaki pada kelompok kontrol

Y : Deviasi/perubahan Nilai sensasi dan pengkajian fisik kaki penderita Diabetes mellitus sebelum dan sesudah senam kaki pada kelompok kontrol

Z : Deviasi/perubahan Nilai sensasi dan pengkajian fisik kaki penderita Diabetes mellitus sebelum dan sesudah senam kaki pada kelompok intervensi dan kelompok kontrol

Populasi target pada penelitian ini adalah penderita Diabetes mellitus yang berobat ke Poliklinik Diabetes mellitus RS Marzoeki Mahdi Bogor dan Poliklinik Penyakit Dalam RS PMI Bogor. Besar sampel minimal berdasarkan hasil perhitungan menggunakan uji hipotesis beda dua mean derajat kemaknaan 5\%, kekuatan uji 90\%, di dapatkan besar sample sebagai berikut :

$$
\begin{aligned}
& \mathrm{n}=\frac{\sigma^{2}\left(\mathrm{z}_{1-\alpha}+\mathrm{z}_{1-\beta}\right)^{2}}{\left(0^{-} \quad \text { a }\right)^{2}} \\
& \mathrm{n}=\frac{1,93^{2}(1,96+1.28)^{2}}{(1,81-2,68)^{2}}=24,87 \rightarrow 25
\end{aligned}
$$

Keterangan;

$\mathrm{n} \quad=$ Jumlah sample minimal

$\mathrm{Z}_{1-\alpha} \quad=$ Nilai $\mathrm{Z}$ pada derajat kemaknaan 1.96 bila $\alpha: 5 \%$

$\mathrm{z}_{1-\beta}=$ Nilai $\mathrm{Z}$ pada kekuatan 1.28 bila $\beta$ : $10 \%$

$\sigma=$ Standar deviasi dari beda dua rata-rata berpasangan penelitian terdahulu yaitu 1,93

$0=$ Rerata nilai sensasi kaki sebelum senam kaki 1,81

a $\quad=$ Rerata nilai sensasi kaki sesudah senam kaki 2,68

Berdasarkan perhitungan dengan menggunakan rumus di atas, sampel yang dibutuhkan dalam penelitian ini adalah 25 orang responden untuk kelompok intervensi dan 25 orang untuk kelompok kontrol. Untuk mengantisipasi drop out maka jumlah sampel diatas ditambah $10 \%$ dari jumlah sampel minimal, sehingga jumlah total sampel menjadi 28 orang untuk kelompok intervensi dan 28 orang untuk kelompok kontrol. Setelah penelitian dilaksanakan didapatkan jumlah sampel sesuai kriteria sebanyak 33 orang untuk kelompok kontrol dan 33 orang kelompok intervensi.

Cara pengambilan sampel pada peneltian ini adalah purposive sampling, yaitu pemilihan sampel sesuai dengan tujuan peneliti dari populasi yang memenuhi kriteria, penelitian (Nursalam, 2003). Dengan kriteria :

a. Penderita Diabetes mellitus usia 40 tahun sampai 65 tahun

b. Penderita Diabetes mellitus $\geq 10$ tahun

c. Penderita Diabetes mellitus yang bersedia melakukan senam kaki

d. Penderita Diabetes mellitus dengan keluhan neuropati diabetik baal, kesemutan, nyeri sendi pada kaki

e. Telah mendapat pengobatan non anabolik (oral) minimal satu tahun

f. Mendapat obat-obatan neurotropik

Analisis data yag digunakan pada penelitian ini diantaranya analisis univariat dan analisis bivariat. Analisis univariat dilakukan 
untuk mendeskripsikan setiap variabel yang diukur dalam penelitian, yaitu dengan distribusi frekuensi. Hasil statistik deskriptif meliputi mean, median, standar deviasi. Deskripsi univariat dilakukan pada setiap variabel yang diteliti yaitu nilai gula darah penderita Diabetes mellitus sebelum dan sesudah senam kaki, nilai sensasi kaki dan pemeriksaan fisik kaki penderita Diabetes mellitus sebelum dan sesudah senam kaki. Uji kesetaraan dilakukan sebelum analisis bivariat, yang merupakan persyaratan uji analisis $\mathrm{t}$ Test. Untuk mengetahui homogenitas data dengan cara membandingkan kesetaraan antara kelompok intervensi dan kelompok kontrol. Data dikatakan setara atau homogen jika $p$ value $>0,05$ dengan menggunakan uji levene's test (Hastono PS, 2007).

\section{HASIL}

Tabel 1. Analisis Nilai Sensasi Kaki dan Pengkajian Fisik Kaki Sebelum dan Sesudah Senam Kaki pada Kelompok Kontrol dan Intervensi

\begin{tabular}{cllrrrr}
\hline \multicolumn{2}{c}{ Variabel } & Jenis Kelp. & Mean & Median & Min - Mak & 95\% CI \\
\hline Sesirifitas & Sebelum & 1. Kontrol & 9.39 & 10 & $7-12$ & $8.87-9.92$ \\
\cline { 3 - 7 } Kaki & senam Kaki & 2. Intervensi & 8.61 & 8 & $7-11$ & $8.15-9.06$ \\
\hline Sesirifitas & Setelah & 1. Kontrol & 9.33 & 9 & $7-12$ & $8.92-9.75$ \\
\cline { 3 - 7 } Kaki & Senam Kaki & 2. Intervensi & 5.55 & 6 & $3-8$ & $4.95-6.14$ \\
\hline Pengkajian & Sebelum & 1. Kontrol & 3.697 & 3.5 & $3-6$ & $3.435-3.959$ \\
\cline { 2 - 7 } Fisik kaki & senam Kaki & 2. Intervensi & 3.712 & 3.5 & $2.5-5.5$ & $3.421-4.003$ \\
\hline Pengkajian & Setelah & 1. Kontrol & 3.848 & 4 & $3-6$ & $3.510-4.187$ \\
\cline { 2 - 7 } Fisik kaki & Senam Kaki & 2. Intervensi & 1.667 & 2 & $1-2.5$ & $1.475-1.858$ \\
\hline
\end{tabular}

Tabel 1 menjelaskan rata-rata nilai sensasi kaki sebelum senam kaki pada kelompok kontrol adalah 9.39, nilai terendah adalah 7 dan tertinggi 12 . Untuk rata-rata nilai sensasi kaki pada kelompok intervensi adalah 8.61 nilai terendah adalah 7 dan tertinggi 11. Hasil analisis di dapatkan rata-rata nilai sensasi kaki penderita neuropati diabetik sesudah senam kaki pada kelompok kontrol adalah 9.33 nilai terendah adalah 7 dan tertinggi 12 . Untuk rata-rata nilai sensasi kaki pada kelompok intervensi adalah 5.55 nilai terendah adalah 3 dan tertinggi 8 .
Rerata nilai pengkajian fisik kaki sebelum senam kaki pada kelompok kontrol adalah 3.697 nilai terendah adalah 3 dan tertinggi 6 . Untuk rata-rata nilai pada kelompok intervensi adalah 3.712 nilai terendah adalah 2.5 dan tertinggi 5.5. Hasil analisis di dapatkan rata-rata nilai pengkajian fisik kaki pada penderita neuropati diabetik sesudah senam kaki pada kelompok kontrol adalah 3.848 nilai terendah adalah 3 dan tertinggi 6. Untuk rata-rata nilai pada kelompok intervensi adalah 1.667 nilai terendah adalah 1 dan tertinggi 2.5 .

Tabel 2. Analisis Pengaruh Senam Kaki terhadap Rata-Rata Nilai Sensasi Kaki dan Pengkajian Fisik Kaki pada Penderita Neuropati Diabetik Kelompok Kontrol dan Intervensi

\begin{tabular}{|c|c|c|c|c|c|c|}
\hline \multirow[t]{2}{*}{ Variabel } & \multirow[t]{2}{*}{ Jenis Kelp. } & \multirow[t]{2}{*}{ Mean } & \multirow[t]{2}{*}{$p$-value } & \multirow[t]{2}{*}{$\mathbf{n}$} & \multicolumn{2}{|c|}{ Perbedaan } \\
\hline & & & & & Mean & SD \\
\hline \multirow{6}{*}{$\begin{array}{c}\text { Sensasi } \\
\text { Kaki }\end{array}$} & 1. Kontrol & & \multirow{3}{*}{0.677} & & \multirow{3}{*}{0.061} & \multirow{3}{*}{0.827} \\
\hline & Sebelum & 9.39 & & 33 & & \\
\hline & Sesudah & 9.33 & & 33 & & \\
\hline & 2. Intervensi & & \multirow{3}{*}{0.000} & & \multirow{3}{*}{3.061} & \multirow{3}{*}{2.045} \\
\hline & Sebelum & 8.61 & & 33 & & \\
\hline & Sesudah & 5.55 & & 33 & & \\
\hline Pengkajian & 1. Kontrol & & \multirow{3}{*}{0.244} & & \multirow{3}{*}{0.1515} & \multirow{3}{*}{0.7340} \\
\hline \multirow{5}{*}{ Fisik Kaki } & Sebelum & 3.697 & & 33 & & \\
\hline & Sesudah & 3.848 & & 33 & & \\
\hline & 2. Intervensi & & \multirow{3}{*}{0.000} & & \multirow{3}{*}{2.0455} & \multirow{3}{*}{0.7843} \\
\hline & Sebelum & 3.712 & & 33 & & \\
\hline & Sesudah & 1.667 & & 33 & & \\
\hline
\end{tabular}



Tabel 2 dapat menjelaskan adanya pengaruh senam kaki terhadap nilai sensasi kaki penderita neuropati diabetik pada kelompok intervensi $(p=0.000, \alpha=0.05)$. Dari tabel di atas dapat dilihat juga terdapat perbedaan rata-rata nilai sensasi kaki yaitu 3.061 point pada kelompok intervensi sebelum dan sesudah senam kaki selama delapan minggu. Dari hasil uji statistik didapatkan nilai 0.000 dengan $\alpha=0.05$ maka dapat disimpulkan ada perbedaan yang signifikan antara nilai sensasi kaki sebelum dan sesudah senam kaki. Terhadap nilai pengkajian fisik kaki penderita neuropati diabetik pada kelompok intervensi $\quad(p=0.000, \alpha=0.05)$. Perbedaan rata-rata nilai pengkajian fisik kaki yaitu 2.0455 point pada kelompok intervensi sebelum dan sesudah senam kaki selama delapan minggu. Uji statistik didapatkan nilai 0.000 dengan $\alpha 0.05$ maka dapat disimpulkan ada perbedaan yang signifikan antara nilai pengkajian fisik kaki sebelum dan sesudah senam kaki.

Tabel 3. Analisis Kesetaraan Nilai Sensasi Kaki dan Pengkajian Fisik Kaki Penderita Neuropati Diabetik antara Kelompok Kontrol dan Intervensi

\begin{tabular}{lllrrrr}
\hline \multicolumn{1}{c}{ Variabel } & & Kelompok. & Mean & T & p-value & \multicolumn{1}{c}{ n } \\
\hline Sensitivitas Kaki & 1. & Kontrol & 9.39 & 2.320 & 0.307 & 33 \\
& 2. & Intervensi & 8.61 & & & 33 \\
\hline Pengkajian Fisik & 1. & Kontrol & 3.697 & 0.079 & 0.502 & 33 \\
Kaki & 2. & Intervensi & 3.712 & & & 33 \\
\hline
\end{tabular}

Tabel 3 menjelaskan bahwa rata-rata nilai sensasi kaki dan pengkajian fisik kaki penderita neuropati diabetik kelompok kontrol dan intervensi mempunyai kesetaraan yang sama (varian sama). Hal ini dapat dilihat dari hasil levene's test yaitu $p$-value lebih besar dari alpha (0.05). Dimana nilai $p$-value sensasi kaki $(0.307$, $\alpha=0.05)$ dan nilai pengkajian fisik pada kaki $(0.5021, \alpha=0.05)$.

Tabel 4. Analisis Perbedaan Rata-Rata Nilai Sensasi Kaki dan Pengkajian Fisik Kaki Penderita Neuropati Diabetik Kelompok Intervensi dan Kontrol Sebelum dan Sesudah Senam Kaki

\begin{tabular}{lllrrrrr}
\hline \multicolumn{2}{c}{ Variabel } & Jenis Kelp. & Mean & SD & SE & p-value & $\mathbf{n}$ \\
& Sesudah & 1. Kontrol & 9.39 & 1.478 & 0.752 & 0.24 & 33 \\
Sensasi Kaki & Senam & 2. Intervensi & 8.61 & 1.273 & 0.222 & & 33 \\
\cline { 2 - 8 } & Sesudah & 1. Kontrol & 9.33 & 1.164 & 0.203 & 0.000 & 33 \\
& Senam & 2. Intervensi & 5.55 & 1.679 & 0.292 & & 33 \\
\hline \multirow{3}{*}{ Pengkajian } & Sesudah & 1. Kontrol & 3.697 & 0.7389 & 0.1286 & 0.937 & 33 \\
Fisik Kaki & Senam & 2. Intervensi & 3.712 & 0.8250 & 0.1427 & & 33 \\
\cline { 2 - 8 } & Sesudah & 1. Kontrol & 3.848 & 0.9559 & 0.1664 & 0.000 & 33 \\
& Senam & 2. Intervensi & 1.667 & 0.5401 & 0.0940 & & 33 \\
\hline
\end{tabular}

Dari tabel 4 Rata-rata nilai sensasi kaki sesudah senam kaki pada Kelompok Kontrol adalah 9.33 dan kelompok intervensi adalah sebesar 5.55. Hasil Uji statistik didapatkan $p$ value adalah 0,000 , pada alpha $5 \%$ terdapat perbedaan rata-rata nilai sensitivitas kaki sesudah senam kaki antara kelompok kontrol dengan kelompok intervensi. Rata-rata nilai pengkajian fisik kaki sesudah senam kaki pada Kelompok Kontrol adalah 3.848 dan kelompok intervensi adalah sebesar 1.667. Hasil Uji statistik didapatkan $p$-value adalah 0,000, pada alpha 5\% terdapat perbedaan rata-rata nilai pengkajian kaki sesudah senam kaki antara kelompok kontrol dengan kelompok intervensi.

\section{PEMBAHASAN}

Tujuan dilakukan penelitian ini seperti telah dijelaskan sebelumnya adalah untuk mengetahui pengaruh senam kaki terhadap nilai gula darah sewaktu dan pengobatan neuropati pada penderita Diabetes mellitus. Diagnosis neuropati diabetik dapat ditentukan salah satunya dengan menggunakan Michigan Neuropathy Screening Instrument (MNSI) (W.H Herman, 2014). MNSI mencakup dua penilaian yang terpisah yaitu sensasi kaki dan pengkajian fisik kaki. Jika nilai sensasi kaki $\geq 7$ maka dianggap neuropati dan jika nilai pengkajian fisik kaki $\geq 2,5$ 
dianggap abnormal atau neuropati (W.H Herman, 2014). Nilai sensasi kaki dan pengkajian fisik kaki pada kelompok intervensi yang telah melaksanakan senam kaki selama delapan minggu dimana tiap minggu tiga kali senam yaitu hari Senin, Rabu dan Jum'at, akan dibandingkan dengan nilai gula darah sewaktu, sensasi kaki dan pengkajian fisik kaki penderita Diabetes mellitus kelompok kontrol yang tidak melaksanakan senam kaki.

\section{Pengaruh Senam Kaki terhadap Pengobatan Neuropati Diabetik pada Penderita Diabetes Mellitus}

Seperti yang sudah dijelaskan di atas bahwa diagnosis neuropati diabetik dapat ditegakkan salah satunya melalui Michigan Neuropathy Screening Instrument (MNSI) yang menilai sensasi kaki dan pengkajian fisik pada kaki. Dari hasil penelitian didapatkan rata-rata nilai sensasi kaki penderita neuropati diabetik pada kelompok intervensi sebelum senam kaki adalah 8.61dan sesudah senam kaki adalah 5.55 berarti nilai sensasi kaki penderita neuropati diabetik mengalami penurunan sebanyak 3.061 point yang berarti keluhan neuropati mengalami penurunan.

Pada kelompok kontrol rata-rata nilai sensasi kaki sebelum intervensi 9.39 dan setelah intervensi 9.33 berarti nilai sensasi kaki penderita neuropati diabetik menurun tidak terlalu banyak hanya sekitar 0.061 point. Hasil uji statistik menunjukkan bahwa senam kaki pada kelompok intervensi berpengaruh secara signifikan dalam menurunkan nilai sensasi kaki penderita neuropati diabetik ( $p=0.000, \alpha=0,05$ ).

Hasil uji statistik juga menunjukkan setelah senam kaki pada kelompok intervensi berbeda bermakna dengan kelompok kontrol $(p=0.000, \alpha=0,05)$, sehingga hasil penelitian ini menunjukkan bahwa dengan senam kaki dapat menurunkan nilai sensasi kaki penderita neuropati diabetik. Dengan demikian dapat disimpulkan pula bahwa senam kaki berpengaruh terhadap pengobatan neuropati diabetik pada penderita Diabetes mellitus.

Didapatkan rata-rata nilai pengkajian fisik kaki penderita neuropati diabetik pada kelompok intervensi sebelum senam kaki adalah 3.712 dan sesudah senam kaki adalah 1.667 berarti nilai pengkajian fisik kaki penderita neuropati diabetik mengalami penurunan sebanyak 2.0455 point yang berarti keadaan fisik kaki penderita mengalami kemajuan atau perbaikan.

Pada kelompok kontrol rata-rata nilai pengkajian fisik kaki sebelum intervensi 3.697 dan setelah intervensi 3.848 berarti nilai pengkajian fisik kaki penderita neuropati diabetik meningkat sekitar 0.1515 point, yang berarti keadaan fisik kaki penderita mengalami penurunan. Hasil uji statistik menunjukkan bahwa senam kaki pada kelompok intervensi berpengaruh secara signifikan dalam menurunkan nilai pengkajian fisik kaki penderita neuropati diabetik $(p=0.000, \alpha=0,05)$.

Hasil uji statistik juga menunjukkan setelah intervensi senam kaki pada kelompok intervensi berbeda bermakna dengan kelompok kontrol $(p=0.000, \alpha=0,05)$, sehingga hasil penelitian ini menunjukkan bahwa dengan senam kaki dapat menurunkan nilai pengkajian fisik kaki penderita DM. Dengan demikian dapat disimpulkan pula bahwa senam kaki berpengaruh terhadap pengobatan neuropati diabetik pada penderita diabetes melitus.

Hasil penelitian di atas sejalan dengan teori yang menyatakan bahwa dampak olah raga antara lain dapat menjadikan sel-sel otot menjadi aktif dan berfungsi seperti insulin sehingga glukosa dapat masuk ke sel otot tanpa bantuan insulin yang kemudian dioksidasi menjadi $\mathrm{CO} 2$ dan air. Olah raga juga dapat meningkatkan kepekaan otot terhadap insulin akibat peningkatan Glut-4 di membran sel otot, kepekaan meningkat selama beberapa jam setelah olahraga, dengan olah raga teratur juga dapat meningkatkan kepekaan terhadap insulin berkepanjangan sehingga mengakibatkan glukosa banyak masuk ke dalam sel. Olah raga juga dapat meningkatkan jumlah dan afinitas reseptor insulin di dalam sel. Reseptor insulin meningkat pada saat kelaparan atau tubuh banyak mengeluarkan energi setelah olah raga dan memfasilitasi glukosa masuk ke dalam sel sehingga dapat menurunkan atau mengontrol gula darah (Smeltzer \& Bare, 2002).

Hasil penelitian di atas sejalan dengan teori yang menyatakan bahwa tujuan yang diperoleh setelah melakukan senam kaki adalah memperbaiki sirkulasi darah pada kaki pasien diabetes mellitus, sehingga nutrisi lancar ke jaringan tersebut (Widianti, 2010). Gerakan dalam senam kaki tersebut seperti yang disampaikan dalam 3rd National Diabetes Educator Training Camp tahun 2005 dapat membantu memperbaiki sirkulasi darah dikaki. Bisa mengurangi keluhan dari neuropati sensorik seperti rasa pegal, kesemutan di kaki (Soegondo, 2011). Senam kaki menjadi salah satu alternatif bagi pasien Diabetes mellitus untuk meningkatkan aliran darah dan memperlancar sirkulasi darah hal ini membuat lebih banyak jala-jala kapiler terbuka sehingga lebih banyak reseptor insulin yang tersedia dan aktif. Kondisi 
ini akan mempermudah saraf menerima nutrisi dan oksigen sehingga dapat meningkatkan fungsi saraf. Senam kaki dapat membuat kontraksi otototot yang menyebabkan terbukanya kanal ion terutama ion positif yang dapat mempermudah aliran penghantaran impuls saraf (Guyton \& Hall, 2001).

Hasil penelitian di atas juga sejalan dengan penelitian yang dilakukan oleh Power (2007) latihan intensitas sedang sampai tinggi akan menyebabkan penggunaan sejumlah besar glukosa dan glikogen otot, sehingga akan meningkatkan penggunaan glukosa darah. Penelitian yang dilakukan oleh Henriksen (2002) latihan aerobik durasi 30-60 menit, dengan intensitas $60-70 \%$ DNM dapat signifikan menurunkan konsentrasi glukosa darah. Pada penelitian yang dilakukan oleh Guelfi (2007) dengan latihan intensits tinggi 80\% DNM selama 30 menit, dapat menurunkan kadar glukosa darah secara signifikan, tetapi bila dibandingkan dengan latihan intensitas sedang penurunan lebih signifikan dibanding dengan latihan intensitas tinggi.

Pada penelitian ini senam kaki dilaksanakan secara kontinyu selama 8 minggu dengan frekuensi 3 kali dalam seminggu. Durasi latihan senam kaki selama 30 menit dengan Intensitas latihan sedang sampai tinggi (70\%$80 \%$ DNM). Bila di lihat dari nilai rata-rata GDS penderita DM pada penelitian ini baik kelompok kontrol maupun intervensi berada pada kisaran $280 \mathrm{mg} \%$ sampai $230 \mathrm{mg} \%$ selain dikontrol oleh aktivitas juga dikarenakan responden sudah dikontrol oleh obat-obat anabolik dan diet.

Hasil penelitian di atas juga sejalan dengan penelitian Karnisius dan Artika tahun 2011 tentang pengaruh senam kaki terhadap sirkulasi darah pasien Diabetes mellitus di RSU Dr. Pringadi Medan, adapun hasil penelitiannya adalah terdapat pengaruh senam kaki yang dilakukan 5 kali dalam seminggu terhadap sirkulasi darah dengan nilai $p=0,000$ (Hareva, 2011). Priyanto S (2012) melakukan penelitian tentang pengaruh senam kaki terhadap sensitivitas kaki dan kadar gula darah pada agregat lansia Diabetes mellitus di Magelang dengan hasil penelitian senam kaki yang dilaksanakan 3 kali seminggu selama 4 minggu adalah kadar gula darah lebih baik pada lansia setelah diberikan senam kaki. Sensitivitas lebih baik pada lansia setelah diberikan senam kaki.

Setelah senam kaki yang dilaksanakan selama 8 minggu dengan frekuensi 3 kali seminggu, durasi 30 menit dan intensitas latihan sedang sampai tinggi (70\%-80\% DNM), dan pelaksanaan senam kaki ditingkatkan dari 1 set menjadi 4 set di mana 1 set terdiri dari 10 hitungan baik kaki kiri maupun kaki kanan. Hasil yang didapatkan untuk pemeriksaan sensasi kaki keluhan yang berkurang atau sampai tidak ada adalah keluhan kaki kesemutan atau mati rasa, kram otot, nyeri kaki, merasa badan lebih enak. Hal ini dapat dibuktikan dengan kesulitan ger kan merobek koran pada awal senam kaki setelah rutin dilaksanakan akhirnya bisa dilakukan.

Untuk pemeriksaan fisik pada kaki yang membaik adalah pada pemeriksaan reflek ankle yang tadinya tidak ada atau ada dengan penguatan menjadi ada dan persepsi getaran yang tadinya menurun atau tida ada menjadi ada. Pada saat pelaksanaan senam kaki target peneliti untuk meningkatkan intensitas latihan dari sedang ke tinggi belum bisa tercapai, walaupun ritme gerakan dipercepat, kemungkinan karena usia responden yang sudah lansia di atas 55 tahun dan akhirnya peneliti menambah gerakan menjadi 4 set gerakan dan kegiatan ini cukup membuat responden mengeluarkan energi yang banyak. Kegiatan senam kaki ini dirasakan bermanfaat untuk penderita neuropati diabetik karena dapat dilakukan di rumah pada saat bangun tidur atau beristirahat duduk dengan waktu yang tidak lama sehingga dapat mengurangi atau mengobati keadaan neuropati diabetiknya.

\section{SIMPULAN}

1. Senam kaki berpengaruh pada nilai sensasi kaki dan pengkajian fisik kaki penderita neuropati diabetik pada kelompok intervensi setelah senam kaki.

2. Terdapat perbedaan yang bermakna pada kelompok intervensi dan kelompok kontrol setelah senam kaki.

3. Senam kaki berpengaruh terhadap pengobatan neuropati diabetik pada penderita Diabetes mellitus.

\section{DAFTAR PUSTAKA}

Barners, E.Darryl. 2012. Program Olahraga: Diabetes Panduan Untuk Mengendalikan Glukosa Darah. Klaten: Citra Aji Parama.
Guelfi KJ, Ratnam N, Smythe GA, Jones TW, Founier PA. 2007. Effect of Intermitten High Intensity Compared with Continous. 
moderat exercise on glucosa production and utilization in individual with type I diabetes. Am J Physiol Endocrinol Metab, 292: E865-E870.

Guyton, Arthur. C., \& Hall. John., E. 2001. Human Physiology and Deseases Mechanism. 3th Ed. (Terjemahan oleh Petrus Adrianto, 2001). Jakarta: Penerbit Buku Kedokteran EGC.

Hareva K dan Sari Artika. 2011. Pengaruh senam kaki terhadap sirkulasi darah kaki pasien Diabetes mellitus di Ruang Penyakit Dalam RSU Dr. Pringadi Medan. Medan: Jurnal Penelitian.

Hastono PS. 2007. Analisis Data kesehatan. Jakarta: Fakultas Kesehatan Masyarakat UI.

Henriksen EJ. 2002. Exercise effects of muscle insulin signaling and action invited. Arizona Department of Physiology, Univercity of Arizona College of Medicine

Herman WH, et all. 2014. Use of the Michigan Neuropathy Screening Instrument as a measure of distal symmetrical peripheral neuropathy in Type 1 diabetes: results from the Diabetes. http://www.ncbi.nlm.nih.gov/pmc/articles/ PMC3641573/ (Diakses pada Maret 2015).

Juliani Nasution. 2011. Pengaruh Senam Kaki terhadap Peningkatan Sirkulasi Darah kaki pada Pasien Penderita Diabetes Mellitus di RSUP H.A.M. Medan: Jurnal Penelitian.

Nursalam. 2003. Konsep dan Penerapan Metodologi Penelitian Ilmu Keperawatan. Edisi 2. Jakarta : Salemba Medika.

Perkeni. 2002. Konsensus Pengelolaan Diabetes mellitus Tipe II di Indonesia. Jakarta: PB Perkeni.

Power SK, Howley ET. 2007. Exercise Physiology Theory and Application to Fitness and Performance. Six edition, USA: Mc. Graw Hill Company.

Priyanto S. 2012. Pengaruh Senam Kaki terhadap Sensitivitas Kaki dan Gula Darah pada Aggregat Lansia Diabetes Mellitus di Magelang. Universitas Indonesia. Depok.

Smeltzer, Suzanne C, Bare, Brenda G. 2002. Buku Ajar Keperawatan Medikal-Bedah Brunner \& Suddarth. Ed.8, Vol.2. Jakarta: EGC.

Soegondo, Sidartawan. 2011. Penatalaksanaan Diabetes Mellitus. Ed. Kedua. Jakarta: FKUI.

Sudoyo Aru. W, dkk. 2006. Buku Ajar Ilmu Penyakit Dalam. Jilid III. Ed. IV. Jakarta: FKUI.

Widianti, Tri Anggriyana. 2010. Senam Kesehatan. Cetakan I. Yogyakarta: Nuha Medika. 